\title{
Rancang Bangung Private Server Menggunakan Platform Proxmox dengan Studi Kasus: PT.MKNT
}

\author{
Danur Wijayanto 1,*, Arizona Firdonsyah ${ }^{2}$, Faisal Dharma Adhinata ${ }^{3}$, Akhmad Jayadi ${ }^{4}$ \\ ${ }^{1,2}$ Fakultas Sains dan Teknologi, Teknologi Informasi, Universitas ‘Aisyiyah Yogyakarta, Indonesia \\ ${ }^{3}$ Fakultas Informatika, Program Studi Rekayasa Perangkat Lunak, Institut Teknologi Telkom Purwokerto, \\ Indonesia \\ ${ }^{4}$ Fakultas Teknik dan Ilmu Komputer, Program Studi Informatika, Universitas Teknokrat Indonesia, Lampung, \\ Indonesia \\ Email: 1, ${ }^{*}$ danurwijayanto@unisayogya.ac.id, ${ }^{2}$ arizona@unisayogya.ac.id , ${ }^{3}$ faisal@ittelkom-pwt.ac.id \\ ${ }^{4}$ akhmad.jayadi@teknokrat.ac.id
}

\begin{abstract}
Abstrak- Teknologi virtualisasi memerankan peran penting Infrastuktur TI meliputi private data centers dan platform public cloud. Ada beberapa jenis virtualisasi yaitu Virtualisasi Container dan Hypervisor. Virtualisasi berbasis container menggunakan kernel yang sama dan bekerja dalam layer software. Container memungkinkan menjalankan beberapa instance sistem operasi dan perangkat keras yang sama. Berbeda dengan container, hypervisor beroperasi pada level hardware memerlukan Operasi Sistem yang terpisah dengan sistem host. Ada beberapa platform virtualisasi yang dapat digunakan seperti Proxmox, VMWare ESX, dan OpenStack. Proxmox mendukung hypervisor KVM (Kernel-based Virtual Machine), dan LXC Container. KVM mempunyai performa CPU yang lebih baik daripada jenis virtualisasi lainnya seperti native, LXC, dan Docker. Penelitian ini bertujuan untuk mengimplementasi virtualisasi di PT.MKNT menggunakan platform virtualisasi PROXMOX. Hasil menunjukkan dengan menggunakan Platform PROXMOX dapat membantu untuk membuat dan mengelola VM dalam private server.
\end{abstract}

Kata Kunci: KVM, AWS, EC2, PROXMOX, LXC, Container

\begin{abstract}
Virtualization technology plays an important role in IT infrastructure including private data centers and public cloud platforms. There are several types of virtualization like Container Virtualization and Hypervisor. Container-based virtualization uses the same kernel and works in software layers. Container allows running multiple instances of the same operating system and hardware. Unlike containers, hypervisors operating at the hardware level, which require separate System Operations with host systems. There are several virtualization platforms that can be used such as Proxmox, VMWare ESX, and OpenStack. Proxmox supports KVM (Kernel-based Virtual Machine) hypervisors, and LXC Containers. KVM has better CPU performance than other virtualization types such as native, LXC, and Docker. This research aims to implement PROXMOX virtualization platform at PT. MKNT to create private server. Results demonstrated by using the PROXMOX Platform can help to create and manage VMs at private server.
\end{abstract}

Keywords: KVM, AWS, EC2, PROXMOX, LXC, Container

\section{PENDAHULUAN}

Teknologi virtualisasi memerankan peran penting Infrastuktur TI meliputi private data centers dan platform public cloud. Teknologi virtualisasi mengijinkan beberapa guest sistem operasi untuk berbagi perangkat keras yang sama dengan linkungan yang terisolasi [1]-[3]. Ada beberapa jenis virtualisasi yaitu Virtualisasi Container dan Hypervisor [4]. Virtualisasi berbasis container menggunakan kernel yang sama dalam menjalankan instance yang banyak dalam satu sistem operasi dan perangkat keras yang sama . Container salah satu solusi yang ringan daripada Virtualisasi Hypervisor. Container mengujinkan untuk menjalankan proses yang terisolasi di sistem host dalam satu Sistem Operasi tanpa overhead berlebih pada CPU dan memory yang disebabkan oleh hypervisor [5], [6]. Kontainer menyediakan lingkugan virtual pada layer aplikasi [7].

Hypervisor merupakan jenis virtualisasi yang telah lama digunakan. Berbeda dengan Container, Hypervisor beroperasi pada level hardware sehingga dapat mengisolasi Virtual Machine(VM) dari sistem host. VM sendiri merupakan virtual komputer yang mempunyai CPU (Central Processing Unit), memory, network interface, media penyimpanan dan sistem operasi sendiri [8]. Hal itu memungkinkan kita menjalankan VM yang menggunakan Sistem Operasi Windows di atas Linux. [5]. Untuk dapat melakukan isolasi VM, hypervisor melakukan manajemen sumber daya fisik seperti CPU, memory, jaringan, dan media penyimpanan.

Teknologi virtualisasi dimanfaatkan untuk menyelesaikan masalah heterogenitas (perbedaan versi library atau tools dari aplikasi website sehingga dapat menguruangi biaya dan kompleksitas hardware serta terciptanya lingkungan yang scalable, elastic, dan biaya yang efisien [5], [6], [9], [10]. Untuk mendukung scalable dan elastic sumber daya dapat diskalakan dengan mengatur jumlah sumberdaya fisik menggunakan Virtual Machine (VM) apabila menerapkan horizontal scaling atau Physical Machine (PM) apabila menerapkan Vertical Scaling [4]. 
Ada beberapa platform virtualisasi yang dapat digunakan seperti Proxmox, VMWare ESX, dan OpenStack. [11], [12]. Proxmox mendukung hypervisor KVM (Kernel-based Virtual Machine), dan LXC Container [1]. Penulis menggunakan PROXMOX karena bersifat open source dan menyediakan web interface untuk mengelola Virtual Machine (VM), media penyimpanan, sumber daya seperti CPU dan RAM [13][3].

KVM menggunakan virtualisasi hardware, sehingga tidak memerlukan untuk meodifikasi sistem operasi host. KVM menggunakan virtualisasi hardware untuk melakukan virtualisasi processor, memory dan I/O [3]. KVM mempunyai performa CPU yang lebih baik daripada jenis virtualisasi lainnya seperti native, LXC, dan Docker [5], [14]. Hasil tersebut yang mendasari penulis untuk menggunakan Platform PROXMOX yang mendukung KVM dikarenakan aplikasi yang dijalankan di server membutuhkan sumber daya CPU yang tinggi untuk pengolahan data.

Penulis melakukan penelitian di PT Mitra Komunikasi Nusantara Tbk (PT MKNT), perusahaan yang bergerak di bidang distribusi produk telekomunikasi [15]. PT MKNT mengembangkan sistem Enterprise Resource Planning (ERP) yang berfungsi untuk memenuhi kebutuhan perusahaan dalam mengakomodasi kebutuhan manajemen data dan informasi proses bisnis dan akuntansi. Sistem tersebut sebelumnya menggunakan layanan komputasi awan dari AWS yaitu Amazon RDS (Amazon Relational Database Service) untuk database dan EC2 (Elastic Computing) untuk menjalankan aplikasi, namun karena perusahaan ingin mengelola sendiri secara private maka dilakukan migrasi dari aws ke server fisik.

AWS merupakan singkatan dari Amazon Web Service yang merupakan salah satu penyedia layanan komputasi awan dengan memberikan layanan yang sesuai kebutuhan pengguna dimana sumber daya disediakan dengan harga murah dan tidak memerlukan pembayaran di awal. Pelanggan hanya harus membayar sesuai sumberdaya yang digunakan. [16]. Penelitian ini bertujuan untuk mengimplementasi virtualisasi di PT.MKNT menggunakan platform virtualisasi PROXMOX dan dapat memberikan manfaat berupa referensi penelitian mengenai pembangunan infrastruktur server memanfaatkan platform virtualisasi PROXMOX.

\section{METODE PENELITIAN}

Dalam subbab ini, akan dijelaskan mengenai metode yang dilakukan penulis dalam melakukan implementasi Platform PROXMOX di server fisik PT MKNT. Terdapat 2 tahap yang penulis gunakan dalam melakukan migrasi, yaitu mengidentifikasi layanan AWS yang sedang digunakan, kemudian melakukan perancangan dan implementasi PROXMOX pada server fisik.

\subsection{Identifikasi Layanan AWS}

Pada tahap ini, peneliti melakukan identifikasi layanan AWS yang digunakan, kemudian dilakukan pemilihan tipe layanan yang dilakukan migrasi dan tidak. Layanan AWS yang digunakan antara lain :

a. Amazon EC2, merupakan layanan komputasi pada cloud yang dapat diubah ukuran dan spesifikasinya. Layanan ini termasuk dalam jenis Iaas (Infrastructur as a Service) [7]. Amazon EC2 menyediakan kontrol penuh pada sumber daya komputasi. Amazon EC2 juga menawarkan beragam pilihan processor, media penyimpanan, jaringan, sistem operasi, dan model pembelian. [17].

b. Amazon RDS, merupakan layanan database relasional untuk MySQL, oracle dan MS SQL Server. AWS RDS memudahkan untuk membuat, mengoperasikan database relasional pada cloud yang menyediakan cost-efficient dan perubahan kapasitas sewaktu-waktu serta terdapat fitur backup otomatis [18], [19].

c. Amazon Route53, merupakan layanan DNS (Domain Name System) yang mendukung high available dan scalable. Amazon Route53 didesain untuk memberikan pengembang aplikasi sebuah layanan yang dapat diandalkan dan cost effective untuk mengarahkan pengguna ke aplikasi dengan cara mentranslasikan nama seperti www.example.com ke alamat IP seperti 192.169.2.1 [20].

d. Amazon S3 (Simple Storage Service), merupakan salah satu layanan penyimpanan yang menawarkan ketersedian data, keamanan, dan performa. Layanan ini dapat digunakan oleh semua jenis pelanggan dan industri untuk menyimpan dan melindungi data dari beragam use case seperti Big Data, website, aplikasi mobile, backup dan restore, archive, aplikasi enterprise, perangkat IoT, dan Big Data Analitics [21].

Tabel 1 menunjukkan daftar layanan AWS yang digunakan dan status apakah akan dilakukan migrasi atau tidak, sedangkan Gambar 1 menunjukkan Topologi layanan AWS yang digunakan.

Tabel 1. Daftar Layanan

\begin{tabular}{cc}
\hline Layanan & Migrasi \\
\hline Amazon EC2 & Ya \\
Amazon RDS & Ya \\
Amazon Route53 & Tidak \\
Amazon S3 & Tidak \\
\hline
\end{tabular}




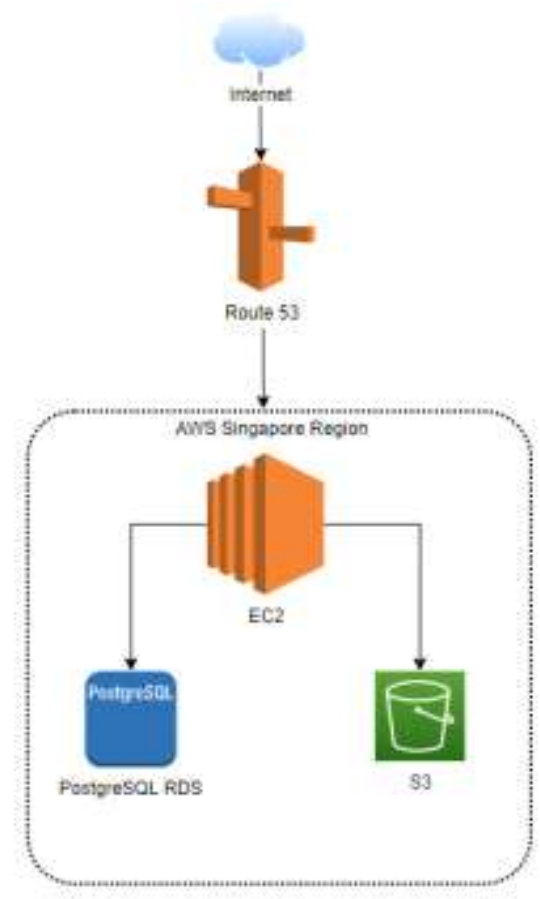

Gambar 1. Topologi Layanan AWS

\subsection{Merancang dan Implementasi PROXMOX pada Server Fisik}

Setelah mengidentifikasi layanan yang akan dimigrasi dari AWS, penulis melakukan desain ulang topologi. Tujuan dari mendesain ulang topologi adalah untuk menyesuaikan kebutuhan yang ada sehingga environtment server dapat berjalan dengan baik, dikarenakan ada beberapa layanan yang masih menggunakan AWS. Topologi baru yang digunakan ditunjukkan pada Gambar 2.

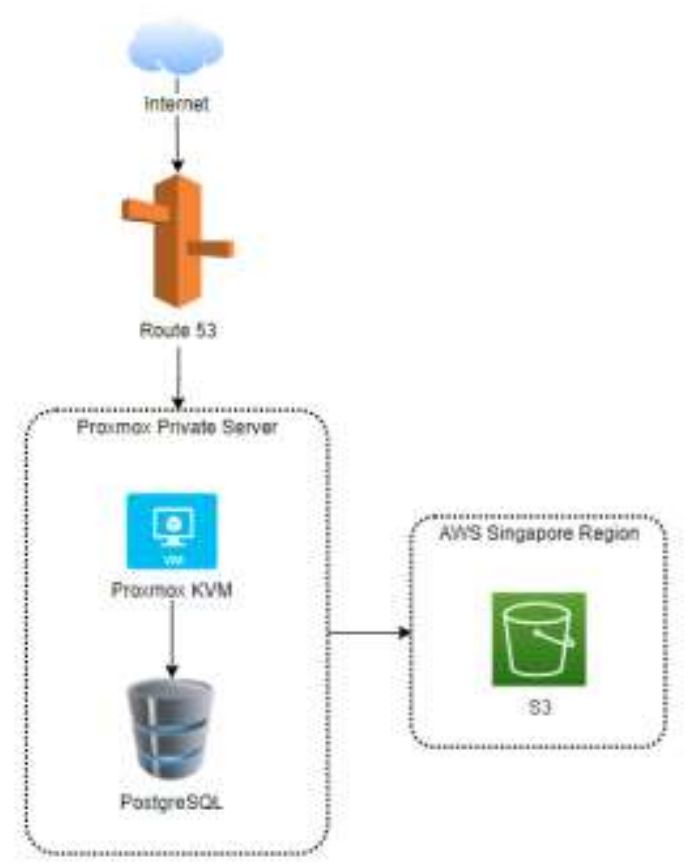

Gambar 2. Rancangan Topologi Private Server dengan Layanan AWS

Pada Gambar 2 menunjukkan gambaran topologi Private Server yang terhubung dengan layanan AWS. Private Server menggunakan platform virtualisasi Proxmox yang kemudian dibuat dua Virtual Machine berbasis KVM, 
yang digunakan untuk menjalankan aplikasi front end dan back end serta database PostgreSQL. Tujuan dari pemisahan database dan aplikasi antara lain adalah untuk memudahkan dalam pengeloaan, dan scaling up.

Setelah selesai melakukan desain ulang topologi server, langkah selanjutnya adalah melakukan implementasi. Server yang digunakan adalah DELL PowerEdge R740 dengan spesifikasi yang ditunjukkan pada Tabel 2. Sedangkan versi Proxmox yang digunakan adalah Proxmox versi 6.2. Sebelum melakukan instalasi Proxmox di server, kita harus mengunduh ISO image di website : https://www.proxmox.com/en/downloads yang kemudian membuat bootable USB atau CD/ DVD sebelum dilakukan proses instalasi. Cara instalasi proxmox ditunjukkan pada Gambar 3.

Tabel 2. Spesifikasi Server

\begin{tabular}{cc}
\hline Jenis & Spesifikasi \\
\hline Processor & Dual Processor CPU(s) Intel(R) Xeon(R) Silver \\
& 4210R CPU @ 2.40GHz \\
RAM (Random Access Memmory) & 384 GB \\
Disk & SSD 2 TB \\
Amazon S3 & Tidak
\end{tabular}

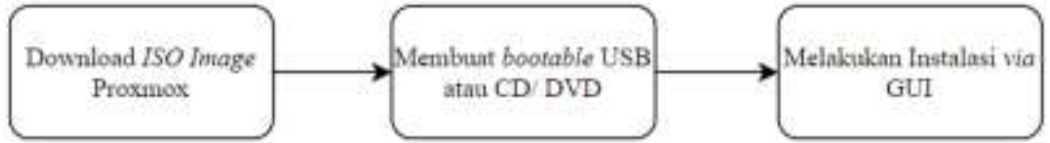

Gambar 3. Langkah - langkah Instalasi Proxmox

\section{HASIL DAN PEMBAHASAN}

Pada bab ini penulis menyajikan hasil implementasi dan pengujian. Pengujian bertujuan untuk mengetahui apakah platform Proxmox dapat berjalan dengan baik. Pengujian dilakukan yang akan dilakukan adalah sebagai berikut : pengujian konektivitas internet VM yang terdiri dari konektivitas dengan pengguna, antar VM dan dengan AWS. Dalam penyajian gambar di bab ini, penulis akan menyamarkan informasi mengenai alamat domain, alamat IP (Internet Protocol), dan beberapa VM yang tidak digunakan dalam penelitian ini dikarenakan data tersebut bersifat rahasia.

\subsection{Hasil Implementasi}

a. Tampilan Web Platform Proxmox

Gambar 4 menunjukkan tampilan Control Panel Proxmox berbasis web. Secara default, alamat web tersebut dapat diakses dengan alamat https://alamat-ip-server:8006.

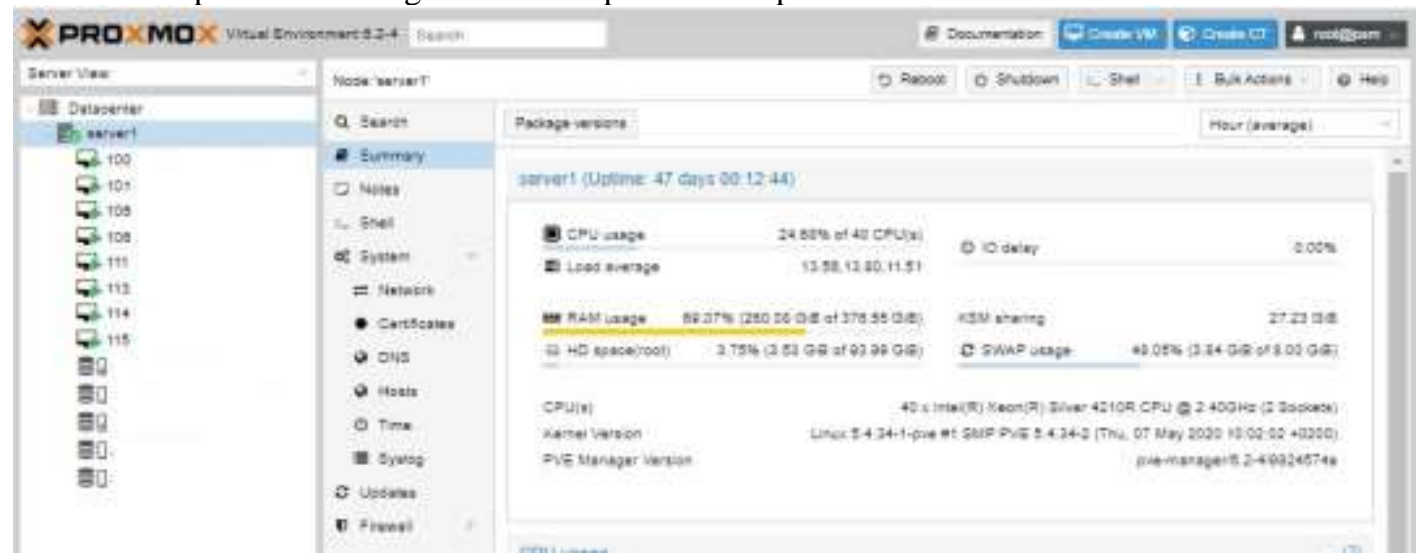

Gambar 4. Tampilan Control Panel Proxmox

b. Implementasi VM

Hasil dari implementasi ini berupa pembuatan dua buah VM dengan hypervisor KVM yang sudah ditunjukkan pada Gambar 2 yang berfungsi untuk menjalankan aplikasi dan Database PostgreSQL. Alur dalam membuat VM ditunjukkan pada Gambar 5. Langkah pertama adalah menentukan nama VM, nama VM yang digunakan harus unik, tidak boleh menggunakan nama yang sudah digunakan. Langkah kedua 
yaitu memilih image sistem operasi yang digunakan. Pada penelitian ini, VM menggunakan Sistem Ubuntu 20.04 LTS (Long Term Support). Langkah ketiga yaitu mengkonfigurasi VM seperti Graphic Card dan Disk Controller. Penelitian ini menggunakan settingan default untuk Graphic Card dan VirtIO SCSI untuk Disk Controller.

Langkah keempat yang mengkonfigurasi ukuran dan jenis hardisk. Penulis menggunakan ukuran yang berbeda untuk kedua VM. Untuk VM dengan ID 105 mempunyai alokasi disk sebesar 400GB, sedangkakan untuk VM dengan ID 121 mempunyai alokasi disk sebesar 200GB. Langkah kelima yaitu menentukan Virtual CPU atau vCPU. Untuk VM dengan ID 105 mempunyai alokasi vCPU sebesar 20 vCPU, sedangkan untuk VM dengan ID 121 mempunyai alokasi 6 vCPU. Langkah keenam adalah mentukan jumlah memory, dimana VM dengan ID 105 mempunyai alokasi memory sebesar 170GB RAM, sedangkan untuk VM dengan ID 121 mempunyai alokasi memory sebesar 48GB RAM. Sedangkan langkah terakhir yaitu mengkonfigurasi perangkat jaringan yang sama - sama menggunakan tipe bridge. VM dengan ID 105 mempunyai alokasi disk, memory, dan $v C P U$ lebih banyak daripada VM dengan ID 121 disebabkan VM dengan ID 105 digunakan sebagai database server. Detail spesifikasi VM dapat dilihat pada Tabel 3 .

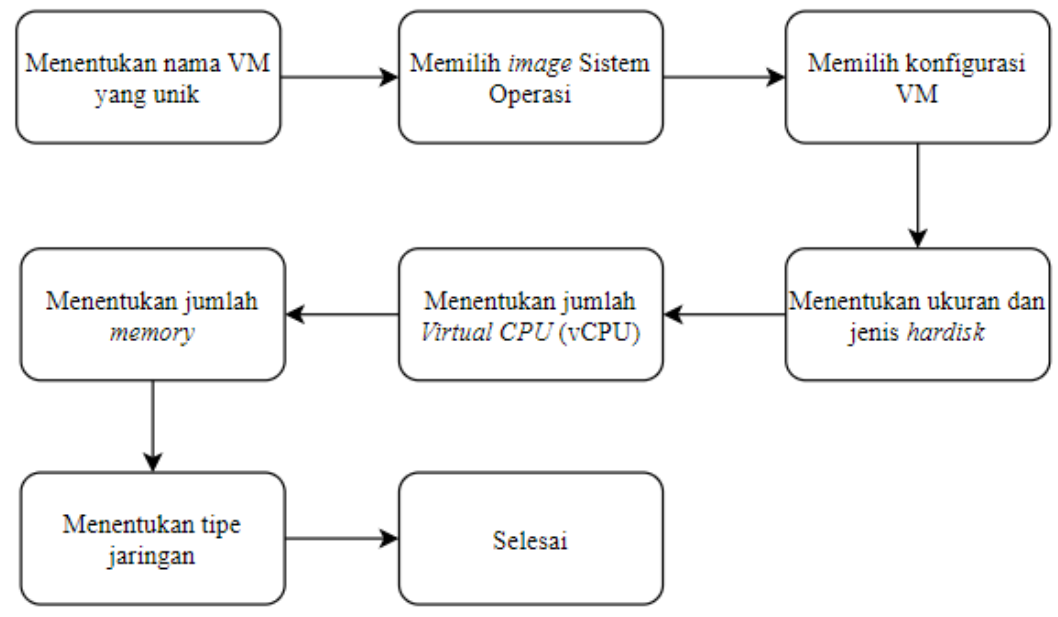

Gambar 5. Alur pembuatan VM

\subsection{Pengujian Konektivitas}

Pada subbab ini akan disajikan hasil pengujian berupa pengujian konektivitas dengan pengguna yaitu pengelola server, konektivitasi antar VM dan konektivitas VM dengan AWS S3. Untuk keperluan pengujian, dibutuhkan 2 VM dengan detail yang ditunjukkan pada Tabel 3 dimana penulis hanya akan menampilkan ID VM dan Hostname keamanan dan kerahasiaan alamat IP Publik.

Tabel 3. Detail VM untuk Pengujian

\begin{tabular}{cccccc}
\hline VM-ID & Hostname & $\begin{array}{c}\text { Alamat IP } \\
\text { Lokal }\end{array}$ & OS & Disk & vCPU \\
\hline 105 & $\begin{array}{c}\text { hp-db- } \\
\text { primary } \\
\text { fe-node-01 }\end{array}$ & 10.0 .1 .83 & Ubuntu 20.04 LTS & 400GB & 20 \\
121 & 10.0 .1 .76 & Ubuntu 20.04 LTS & 200GB & 6 \\
\hline
\end{tabular}

\subsubsection{Konektivitas dengan Pengguna}

Pengujian konektivitas dengan pengguna dilakukan dengan menggunakan pengujian pengiriman paket ICMP (Internet Control Message Protocol) dari VM ke suatu domain (pada penelitian ini menggunakan alamat google.com) dan akses server memanfaatkan protokol SSH (Secure Shell) menggunakan aplikasi putty.

a. Pengiriman Paket ICMP

Gambar 6 menunjukkan pengiriman paket ICMP dari VM dengan ID 105. sedangkan Gambar 7 menunjukkan pengiriman paket ICMP dari VM dengan ID 121. Dari kedua hasil pengujian tersebut, 
dihasilkan packet loss sebesar 0\%. Sehingga dapat disimpulkan pengiriman paket ICMP sukses dan VM dapat mengakses jaringan internet.

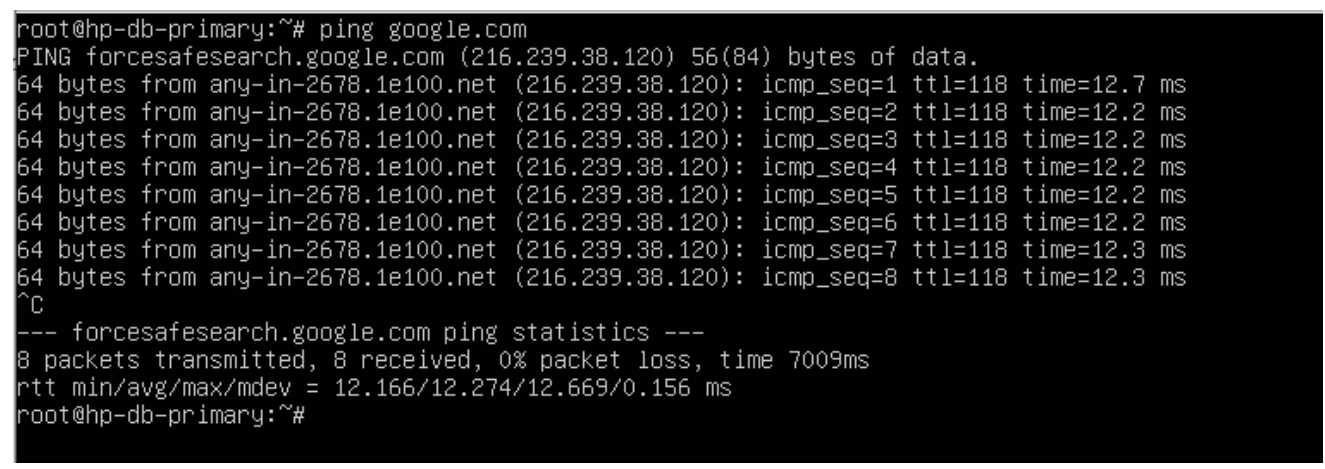

Gambar 6. Hasil Pengiriman Paket ICMP VM dengan ID 105

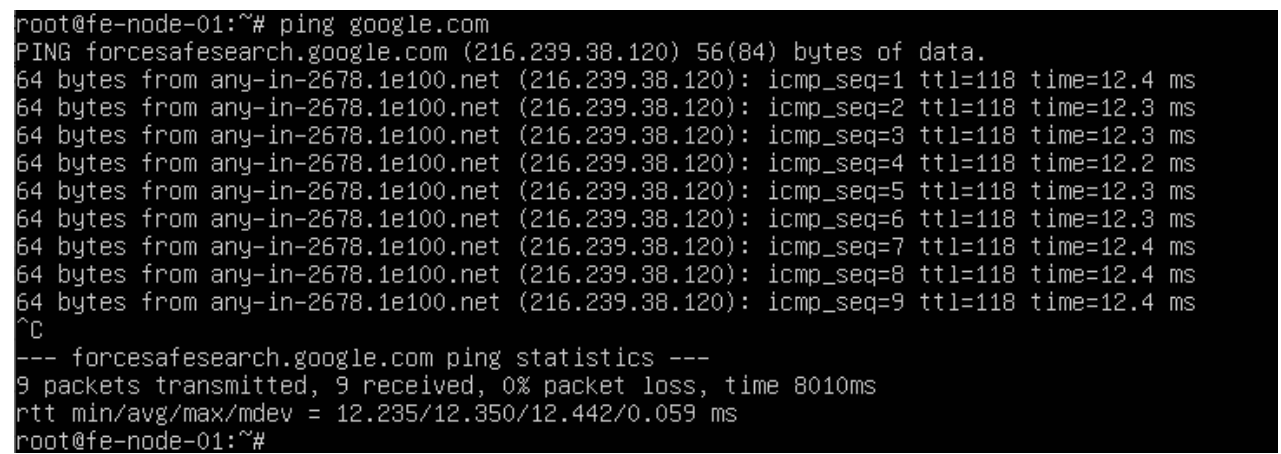

Gambar 7. Hasil Pengiriman Paket ICMP VM dengan ID 121

b. Akses Server Menggunakan Putty

Gambar 8 menunjukkan hasil remote ke VM dengan ID 105 menggunakan putty, sedangkan Gambar 9 menunjukkan hasil remote ke VM dengan ID 121 menggunakan putty. Dari kedua hasil pengujian tersebut, administator server sukses mengakses kedua VM. Sehingga dapat disimpulkan pengujian akses server sukses dan VM dapat dikelola secara remote atau jarak jauh.

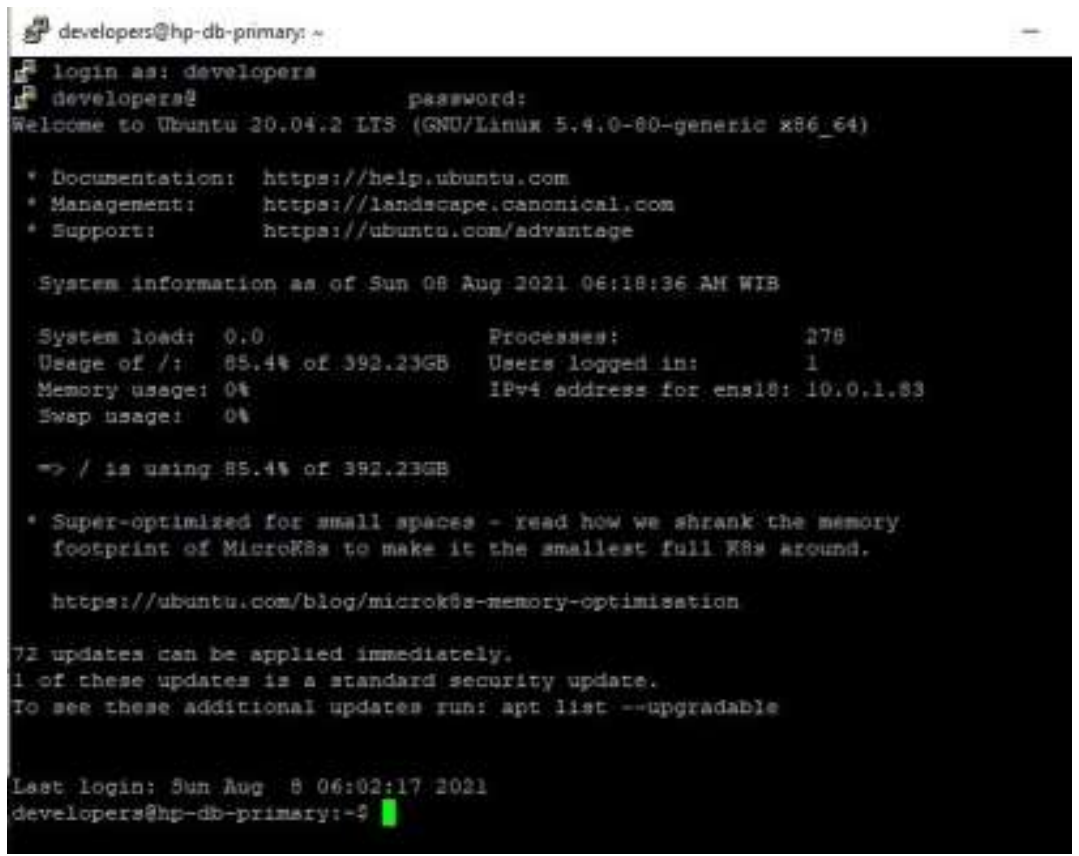

Gambar 8. Hasil Remote menggunakan putty ke VM dengan ID 105 


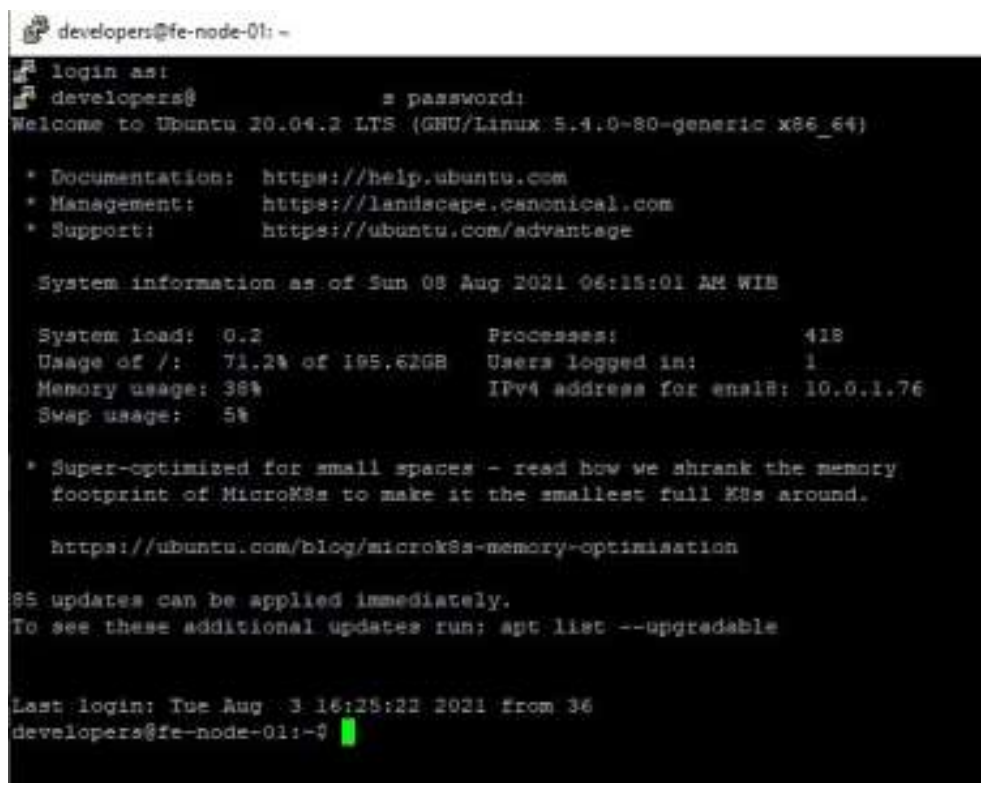

Gambar 9. Hasil Remote menggunakan putty ke VM dengan ID 121

\subsubsection{Konektivitas antar VM}

Pengujian konektivitas antar VM dilakukan dengan menggunakan pengujian pengiriman paket ICMP antar kedua VM. Dalam pengujian konektivitas ini, IP yang digunakan adalah IP Lokal, karena VM berada dalam satu jaringan dan server yang sama. Alamat kedua VM ditunjukkan pada Tabel 3. Hasil yang ditunjukkan pada Gambar 10 dan Gambar 11 menunjukkan paket ICMP dapat terkirim dengan sempurna yang dibuktikan dengan packet loss sebesar 0\%. Sehingga dapat disimpulkan pengiriman paket ICMP sukses dan VM dapat saling berkomunikasi.

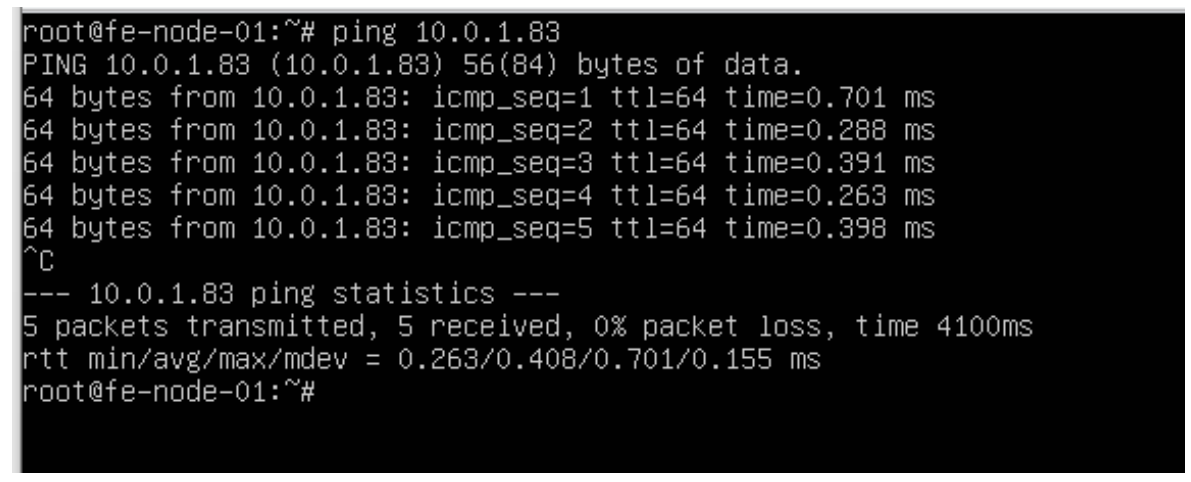

Gambar 10. Hasil ping dari VM dengan ID 121 ke VM dengan ID 105

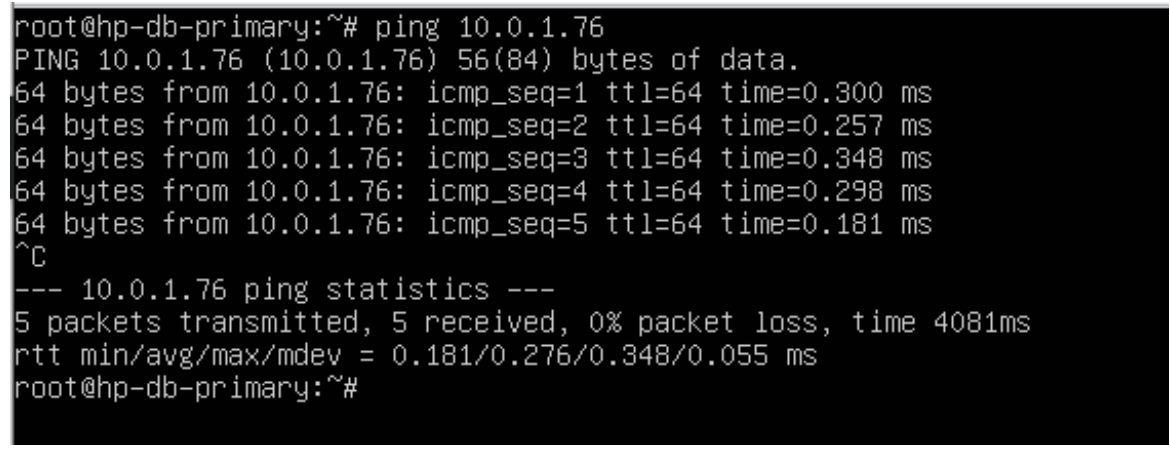

Gambar 11. Hasil ping dari VM dengan ID 105 ke VM dengan ID 121

\subsubsection{Konektivitas dengan AWS S3}

Pengujian konektivitas dengan AWS dilakukan dengan melakukan upload dan download file ke AWS S3. Pengujian ini hanya menggunakan VM dengan ID 105 yang membutuhkan koneksi ke AWS S3 untuk 
keperluan backup. Sebelum dilakukan pengujian konektivitas ini, perlu dilakukan instalasi AWS Command Line Interface (CLI) supaya dapat terhubung ke AWS S3 serta membuat bucket di AWS S3. Gambar 12 menyunjukkan bucket yang telah dibuat dengan nama ag-my-backup, kemudian pada Gambar 13 menunjukkan proses ujicoba konektivitas dengan melakukan upload beberapa file ke bucket AWS yang beralamat di s3://ag-my-backup. Setelah proses upload selesai, dapat dilihat pada Gambar 14 bahwa file file tersebut sudah sukses dan terbaca pada bucket. Dengan demikian, dapat disimpulkan bahwa VM sukses terkoneksi dengan AWS S3.

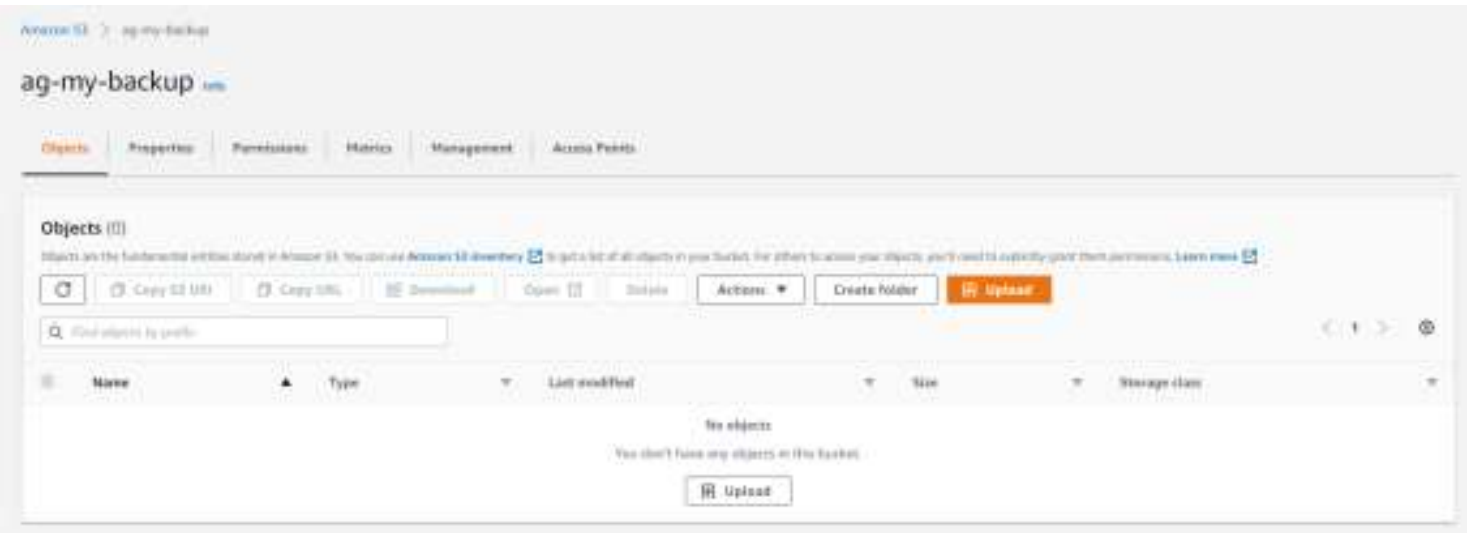

Gambar 12. S3 Bucket

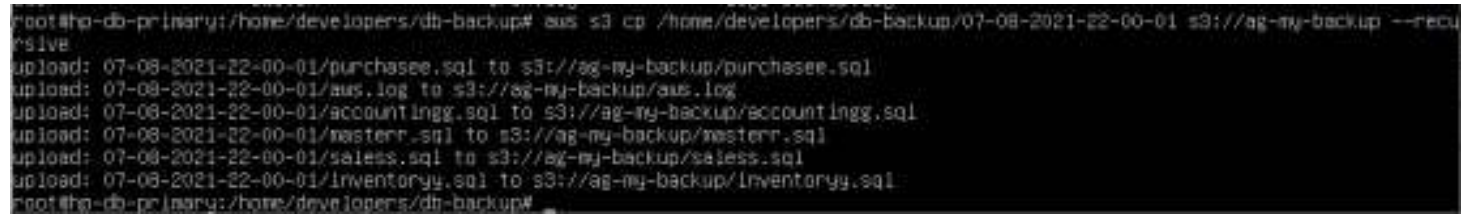

Gambar 13. Proses Transfer Data ke AWS S3

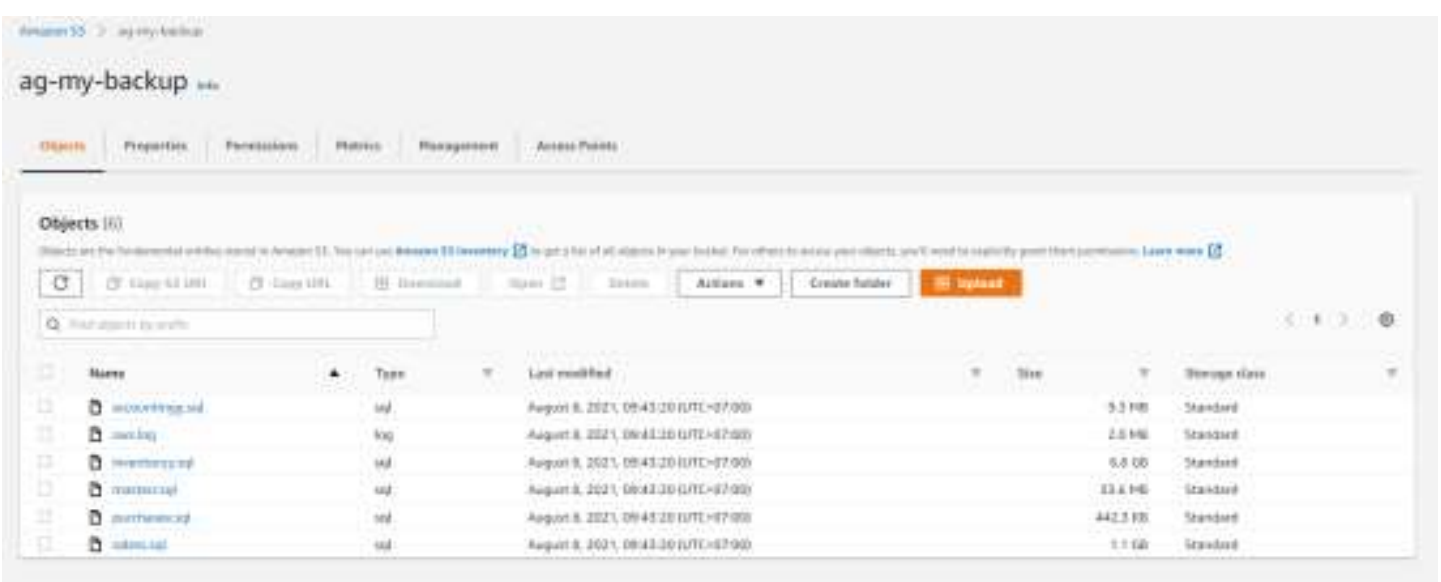

Gambar 14. Isi dari S3 Bucket setelah Proses Transfer Data

Tabel 4 menunjukkan rangkuman ujicoba yang telah dilakukan. Dari tabel tersebut, dapat disimpulkan bahwa keseluruhan ujicoba dilakukan dengan sukses.

Tabel 4. Rangkuman Ujicoba

\begin{tabular}{clc}
\hline No & \multicolumn{1}{c}{ Pengujian } & \multicolumn{1}{c}{ Hasil } \\
\hline 1 & $\begin{array}{l}\text { Konektivitas } \\
\text { dengan pengguna }\end{array}$ & sukses terhubung \\
2 & $\begin{array}{l}\text { Konektivitas antar } \\
\text { VM }\end{array}$ & sukses terhubung \\
& $\begin{array}{l}\text { Konektivitas } \\
\text { dengan AWS s3 }\end{array}$ & sukses terhubung \\
\hline
\end{tabular}




\section{KESIMPULAN}

Dari hasil implementasi dan pengujian yang telah dilakukan dapat ditarik kesimpulan bahwa dengan menggunakan Platform Proxmox dapat dilakukan implementasi topologi yang mirip dengan topologi yang digunakan perusahaan pada AWS, serta dapat membantu untuk membuat dan mengelola VM dalam private server. Dalam lingkungan Proxmox juga memungkinkan antar VM untuk saling berkomunikasi menggunakan IP Local, sehingga tidak perlu memerlukan IP Public. Penelitian selanjutnya diharapkan dapat meneliti mengenai High Availability atau Load Balancing pada Platform Proxmox

\section{UCAPAN TERIMAKASIH}

Terima kasih disampaikan kepada Ginanjar Budhiraharja, S.I.P., M.M. selaku IT Project Manager di PT. Mitra Komunikasi Nusantara Tbk yang telah mengijinkan penulis untuk menyelesaikan penelitian ini serta pihak-pihak yang telah mendukung terlaksananya penelitian ini.

\section{REFERENCES}

[1] S. A. Algarni, M. R. Ikbal, R. Alroobaea, A. S. Ghiduk, and F. Nadeem, "Performance Evaluation of Xen, KVM, and Proxmox Hypervisors:", Int. J. Open Source Softw. Process., vol. 9, no. 2, pp. 39-54, Apr. 2018, doi: 10.4018/IJOSSP.2018040103.

[2] P. China Venkanna Varma, V. K. C. K., V. Valli Kumari, and S. Viswanadha Raju, "Analysis of a Network IO Bottleneck in Big Data Environments Based on Docker Containers," Big Data Res., vol. 3, pp. 24-28, Apr. 2016, doi: 10.1016/j.bdr.2015.12.002.

[3] A. Kovari and P. Dukan, "KVM \& OpenVZ virtualization based IaaS open source cloud virtualization platforms: OpenNode, Proxmox VE," in 2012 IEEE 10th Jubilee International Symposium on Intelligent Systems and Informatics, Subotica, Serbia, Sep. 2012, pp. 335-339. doi: 10.1109/SISY.2012.6339540.

[4] X. Wan, X. Guan, T. Wang, G. Bai, and B.-Y. Choi, “Application deployment using Microservice and Docker containers: Framework and optimization,” J. Netw. Comput. Appl., vol. 119, pp. 97-109, Oct. 2018, doi: 10.1016/j.jnca.2018.07.003.

[5] R. Morabito, J. Kjallman, and M. Komu, "Hypervisors vs. Lightweight Virtualization: A Performance Comparison," in 2015 IEEE International Conference on Cloud Engineering, Tempe, AZ, USA, Mar. 2015, pp. 386-393. doi: 10.1109/IC2E.2015.74.

[6] C. de Alfonso, A. Calatrava, and G. Moltó, "Container-based virtual elastic clusters," J. Syst. Softw., vol. 127, pp. 1-11, May 2017, doi: 10.1016/j.jss.2017.01.007.

[7] M. Uehara, "Performance Evaluations of LXC Based Educational Cloud in Amazon EC2," in 2016 30th International Conference on Advanced Information Networking and Applications Workshops (WAINA), Crans-Montana, Switzerland, Mar. 2016, pp. 638-643. doi: 10.1109/WAINA.2016.24.

[8] "What is a virtual machine (VM)?" https://www.redhat.com/en/topics/virtualization/what-is-a-virtual-machine (accessed Aug. 28, 2021).

[9] Sulastri Apridayanti, Isnawaty, and Rizal Adi Saputra, "Desain Dan Implementasi Virtualisasi Berbasis Docker Untuk Deployment Aplkasi Web," Oct. 2018, doi: 10.5281/ZENODO.1407862.

[10] W. Li and A. Kanso, "Comparing Containers versus Virtual Machines for Achieving High Availability," in 2015 IEEE International Conference on Cloud Engineering, Tempe, AZ, USA, Mar. 2015, pp. 353-358. doi: 10.1109/IC2E.2015.79.

[11] M. Riasetiawan, A. Ashari, and I. Endrayanto, "Distributed Replicated Block Device (DRDB) implementation on cluster storage data migration," in 2015 International Conference on Data and Software Engineering (ICoDSE), Yogyakarta, Indonesia, Nov. 2015, pp. 93-97. doi: 10.1109/ICODSE.2015.7436978.

[12] A. Arfriandi, "Perancangan, Iimplementasi, dan Analisis Kinerja Virtualisasi Server Menggunakan PROXMOX, VMWARE ESX, dan OPENSTACK," J. Teknol., vol. 5, no. 2, pp. 182-192, 2012.

[13] L. Chen, W. Huang, A. Sui, D. Chen, and C. Sun, "The online education platform using Proxmox and noVNC technology based on Laravel framework," in 2017 IEEE/ACIS 16th International Conference on Computer and Information Science (ICIS), Wuhan, China, May 2017, pp. 487-491. doi: 10.1109/ICIS.2017.7960041.

[14] W. Felter, A. Ferreira, R. Rajamony, and J. Rubio, "An updated performance comparison of virtual machines and Linux containers," in 2015 IEEE International Symposium on Performance Analysis of Systems and Software (ISPASS), Philadelphia, PA, USA, Mar. 2015, pp. 171-172. doi: 10.1109/ISPASS.2015.7095802.

[15] “About Us," About PT Mitra Komunikasi Nusantara Tbk. https://www.mknt.id/about (accessed Jul. 28, 2021).

[16] S. Narula, A. Jain, and Prachi, "Cloud Computing Security: Amazon Web Service," in 2015 Fifth International Conference on Advanced Computing \& Communication Technologies, Haryana, India, Feb. 2015, pp. 501-505. doi: 10.1109/ACCT.2015.20.

[17] “AWS EC2,” Amazon EC2. https://aws.amazon.com/ec2 (accessed Jul. 28, 2021).

[18] S. Mukherjee, "Benefits of AWS in Modern Cloud," SSRN Electron. J., 2019, doi: 10.2139/ssrn.3415956.

[19] “AWS RDS,” Amazon RDS. https://aws.amazon.com/rds (accessed Jul. 28, 2021).

[20] “AWS Route53,” Amazon Route53. https://aws.amazon.com/route53 (accessed Jul. 28, 2021).

[21] “AWS S3,” Amazon S3. https://aws.amazon.com/s3 (accessed Jul. 28, 2021). 